\title{
HOW FUTURE PROPULSION SYSTEMS INFLUENCE FUTURE COMPONENT TESTING: LATEST RESULTS FROM STUTTGART UNIVERSITY'S ALTITUDE TEST FACILITY
}

\author{
Constanze Schiewe \\ Institute of Aircraft Propulsion Systems, \\ University of Stuttgart \\ Stuttgart, Germany
}

\author{
Nicolas Neuburger \\ Institute of Aircraft Propulsion Systems, \\ University of Stuttgart \\ Stuttgart, Germany
}

\author{
Stephan Staudacher \\ Institute of Aircraft Propulsion \\ Systems, University of \\ Stuttgart \\ Stuttgart, Germany
}

\begin{abstract}
A modern air transportation network with steadily increasing passenger numbers and strict environmental rules requires highly efficient propulsion systems. The required efficiency gains demand for tests with higher temporal and spatial resolution as well as increased requirements with regard to the range and quality of test conditions.

Based on these requirements of modern propulsion systems the corresponding modifications and enhancements with respect to future component testing by example of Stuttgart University's Altitude Test Facility were determined. Beyond increasing test vehicle inlet pressure and temperature the focus is on the enhancement of the automation level. The resulting improvement of testing quality and repeatability is covered. The article closes with a comparison with other test facilities regarding to their ability of testing future propulsion systems.
\end{abstract}

Keywords: Altitude Test Facility, future component testing, future propulsion systems, engine testing, turbine testing, combustor testing, operational concept, control system

\section{INTRODUCTION}

Highly efficient propulsion systems are the basis of an effective and environmental friendly air transportation network. With today's turbojet engines representing a mature technology, further technical development requires more and more advanced design systems with ever increasing temporal and spatial resolution. Experimental methods used for calibration of the design systems as well as the validation of the designed product have to keep pace with this development.
This translates not only into increased stability and repeatability of test conditions but also into an increased range of operating conditions reflecting the thermodynamic cycles of future engines. These requirements are accompanied by an ever rising economic pressure to reduce test time and test cost.

Responding to these increasing requirements the Institute of Aircraft Propulsion Systems (ILA) and its partners MTU Aero Engines and Rolls Royce Deutschland currently are carrying out the Project "FoTeKo" (Advanced Technology and Test concepts for Turbines, Combustors and Core Engines). Stuttgart University's contribution to FoTeKo is divided into 3 sub-projects. First sub-project leads to performance improvements for future combustor altitude relight testing. The second sub-project results in advances for future turbine aerodynamic testing. The third sub-project enhances the agility of the test facility as required by the operation of today's highly instrumented core engine demonstrators featuring a high level of automation of the test facility.

\section{REQUIREMENTS OF ENGINE SUB-SYSTEM TESTING}

Advisory Council for Aviation Research and innovation in Europe (ACARE) published flight path 2050 goals, which provides a reduction of $\mathrm{CO}_{2}$ emissions by $75 \%, \mathrm{NO}_{\mathrm{x}}$ by $90 \%$ and perceived noise by $65 \%$ relative to the year 2000 (ACARE, 2017). 
This goals result in an increasing challenge to fulfil the more and more stringent environmental standards and can be achieved by application of lean burn technologies.

The flow field of this technology is currently not investigated in detail (Von der Bank et al., 2014). This implies, examining it experimentally will be part of future combustor tests.

To verify the altitude relight capability of the novel combustor technique the following quality attributes have to be fulfilled by the test bed:

- Fuel conditioning which delivers a wide range of fuel temperatures and pressures at the combustor manifold with a special emphasis on low fuel temperatures,

- Stable combustor flow conditions with a minimum impact of the lighting process,

- Repeatable and reliable thermodynamic detection of lighting and pull-away.

These requirements form the basis of the first sub-project (SP-1) of the ILA contribution to FoTeKo.

To accomplish the flight path 2050 goals, there are also projects additionally investigating potential further development of other components and whole engines. One of these projects is LEMCOTEC, which sees highest potential for improvements in the field of thermal efficiency of the coreengine technology. To improve the thermal efficiency, the overall pressure ratio (OPR) has to increase. (Von der Bank et al., 2014)

As well the historical development shows this direction as can be seen in Fig. 1 .

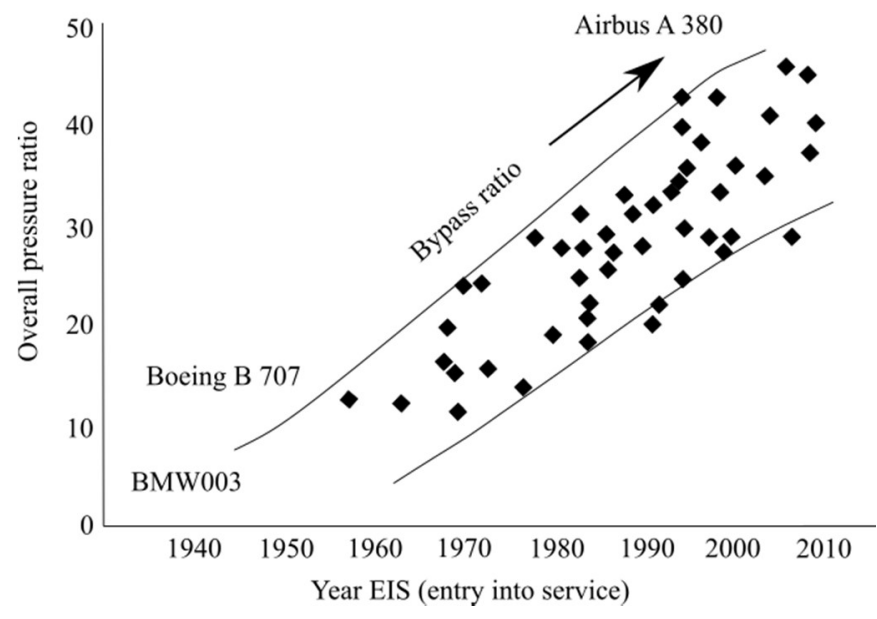

Figure 1: Development of the OPR (following Rick, 2013)

Increasing bypass ratios in association with increasing overall pressure ratios (see Fig. 1) result in a raise in low pressure turbine expansion ratios. In combination with the Reynolds number level of today's and future engine's low pressure turbine rear stages this trend results in the quality attributes of low pressure turbine aerodynamic testing listed below:

- an increase of rig inlet temperatures reflecting the limits of the inserted instrumentation,

- $\quad$ an increase of rig inlet pressures as well as

- an increase in rig pressure ratio,

- long-time stability of operating conditions even at extremely low pressure levels.

These requirements form the basis of the second subproject (SP-2) of the ILA contribution to FoTeKo.

In this context core testing can be regarded as a possible next step in terms of engine sub-system testing. Today's core engine demonstrators are highly instrumented and serve a multitude of interdisciplinary validation tasks. Generally there are two modes of core engine testing in an altitude test facility. In the first mode very stable and repeatable operating conditions have to be provided. In this mode the ATF controls has to react to any power level changes of the core engine. In the second mode the LP system of the full engine is simulated by the ATF. This requires transient operation of the ATF with the rates of change of pressures and temperatures typical for an engine's LP system. With the core engine being controlled by an electronic engine control the human reaction for adjusting the ATF conditions at core inlet and exit will not be sufficient. Hence this process has to be automated. These requirements form the basis of the third sub-project (SP-3) of the ILA contribution to FoTeKo.

In the light of continuously decreasing development times in the aircraft propulsion industry component and core tests have to become more efficient. This includes an increased rate of useful test results per test time leading to higher levels of instrumentation of the test vehicles as well as more and more packed test programs. For the ATF operation this translates into a high ratio of measurement to transition times. In this context the heating or cooling time has to be shortened by suitable methods. These more general requirements also have to be considered in SP-1 and SP-2 of the ILA contribution to FoTeKo.

\section{FOTEKO STARTING POINT}

Stuttgart University's Altitude Test Facility (ATF) continuously is subject to extensions and improvements (e.g. Hechtel, 1987, Braig et al., 1987). A multitude of very successful engine, core engine (e.g. Gonser, 2008; Klinger et al., 2011), piston engine, turbine (e.g. MTU Aero Engines, 2011) and combustor tests (e.g. Clemen et al., 2017) underlines the strategic focus as a highly versatile and effective test facility.

The complexity of engine tests realized at this facility is revealed by Fig. 2 and 3 documenting an engine and a turbine test. 


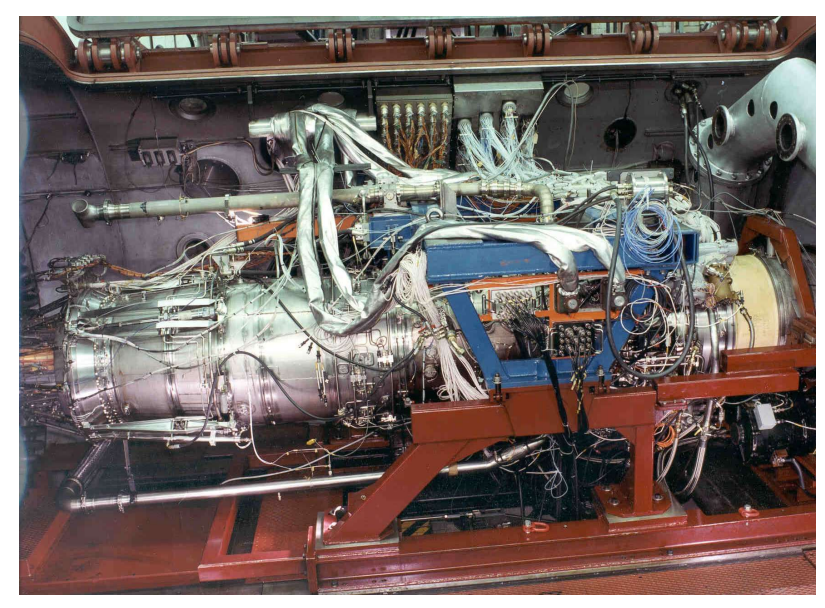

Figure 2: Engine test configuration

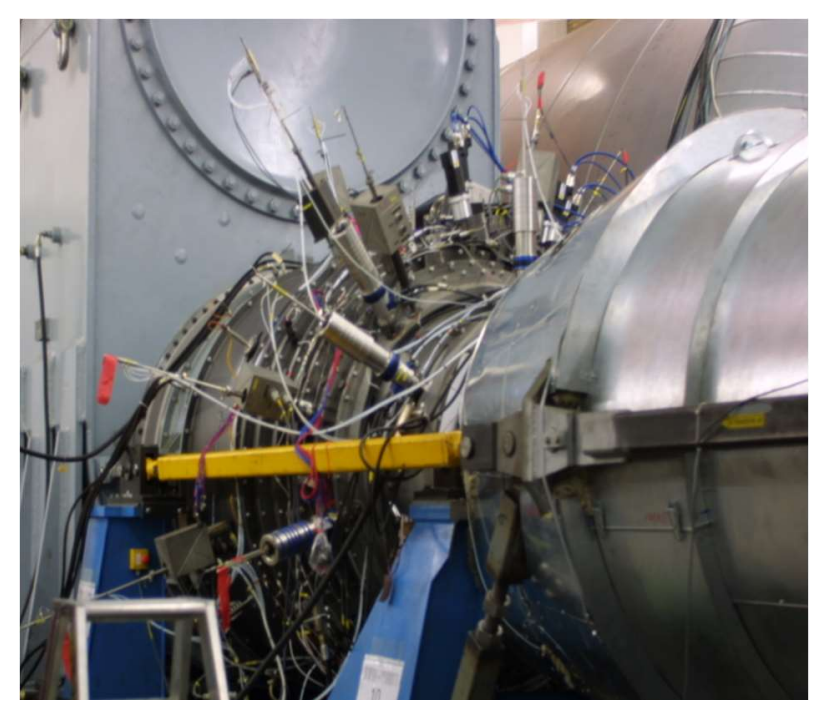

Figure 3: Turbine test configuration

The required flexibility of the test facility configuration is ensured by the provision of two test cells which are supplied with air by a combination of compressors and heat exchangers. A multitude of valves allows a highly flexible configuration of this system.

A generalized and simplified scheme of the ATF is provided in Fig. 4. The green parts are the components which are described in the sub-projects.

At the outset of FoTeKo the ATF featured the following base performance parameter:

- $\quad$ minimum pressure: $\mathrm{p}_{\mathrm{i}, \mathrm{min}}=5 \mathrm{kPa}$

- maximum pressure: $\mathrm{p}_{\mathrm{i}, \max }=240 \mathrm{kPa}$

- minimum temperature: $T_{i, \min }=210 \mathrm{~K}$

- maximum temperature: $T_{\mathrm{i}, \max }=430 \mathrm{~K}$

- maximum mass flow: $\dot{\mathrm{m}}_{\mathrm{f}}=130 \mathrm{~kg} / \mathrm{s}$,

Whilst this already leads to a wide range of operating conditions, the future test campaigns will require a specific extension of these parameters as described above. The resulting advancements are described below in the sequence of the FoTeKo sub-projects.

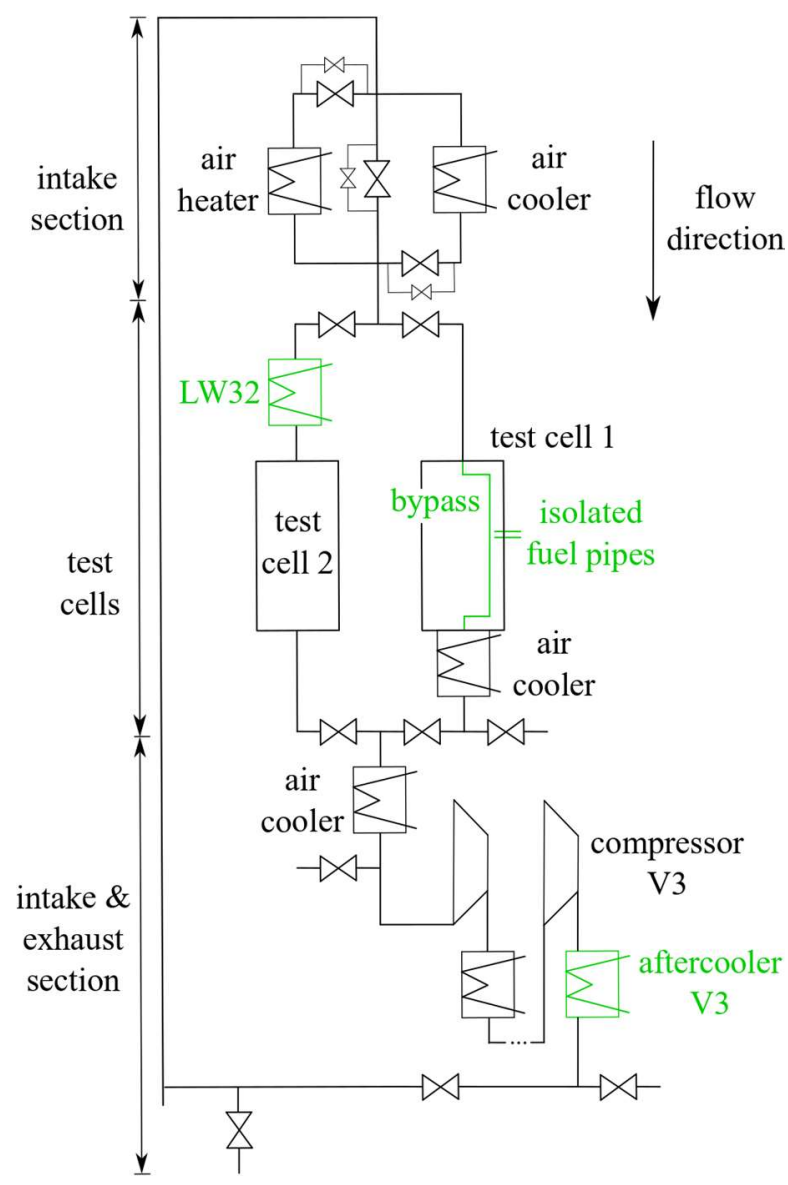

Figure 4: Generalized ATF Scheme

\section{SP-1: IMPROVEMENTS FOR FUTURE COMBUSTOR ALTITUDE RELIGHT TESTING}

During combustor altitude relight testing lighting and pull-away is detected using thermocouples, total pressure probes and static pressure tapings are positioned in the exit annulus of the combustor rig. Until now 6 measurement points have been located along the perimeter of the combustor exit annulus. This instrumentation has been part of the combustor rigs exhaust casing. The spatial resolution of the measurements has been increased to improve the reliability and the sensitivity of the detection.

In the course of project FoTeKo new exhaust casings with an increased number of measurement positions have been designed and manufactured. The exhaust casings now feature a modular structure including an adapter ring with removable plates in which the sensors are installed. Tests of combustors with varying burner numbers are now set up more effectively by only replacing the adapter ring and the plates. In addition this design leads to an increased service life of the pressure probes and the thermocouples. To additionally assist the evaluation of the test results a display is provided in the control room, showing the conditions in each section of the combustor exit (see Fig. 5). When ignition occurred, the local thermal load is indicated by a colour code and the according pressure and temperature values. 


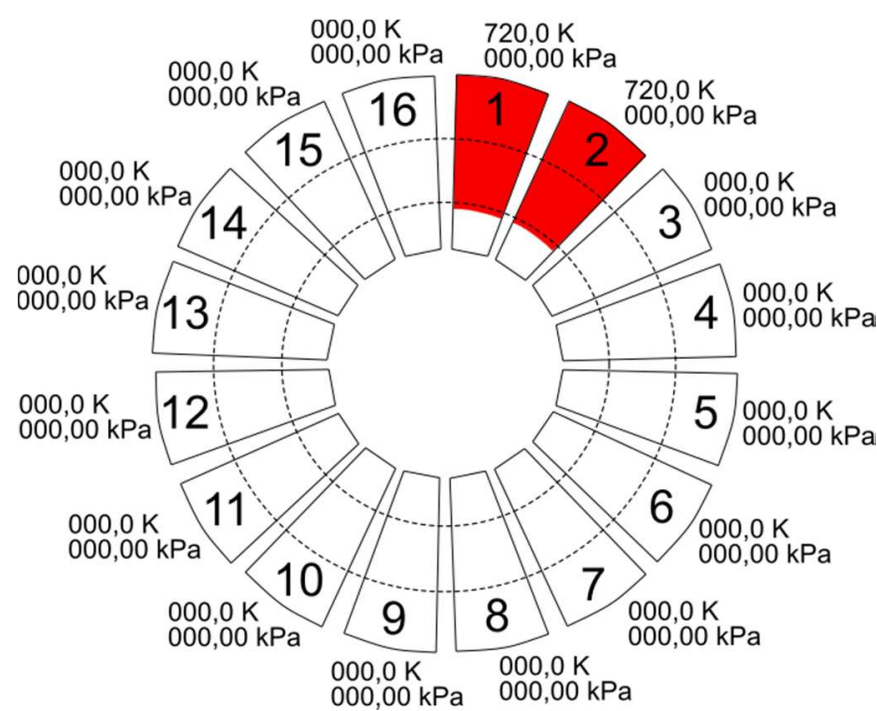

Figure 5: Control Room Display for Combustor Altitude Relight Testing

The envisaged high ratio of measurement to transition times involves shortening the heating or cooling time during combustor altitude relight testing. Generally raising the air mass flow through the facility is a very effective mean for shortening the cooling and heating times. Since the air mass flow through combustors is low during altitude relights, bypassing the air around the rig is required. Such a bypass system has been realized in FoTeKo as shown in Fig. 6.

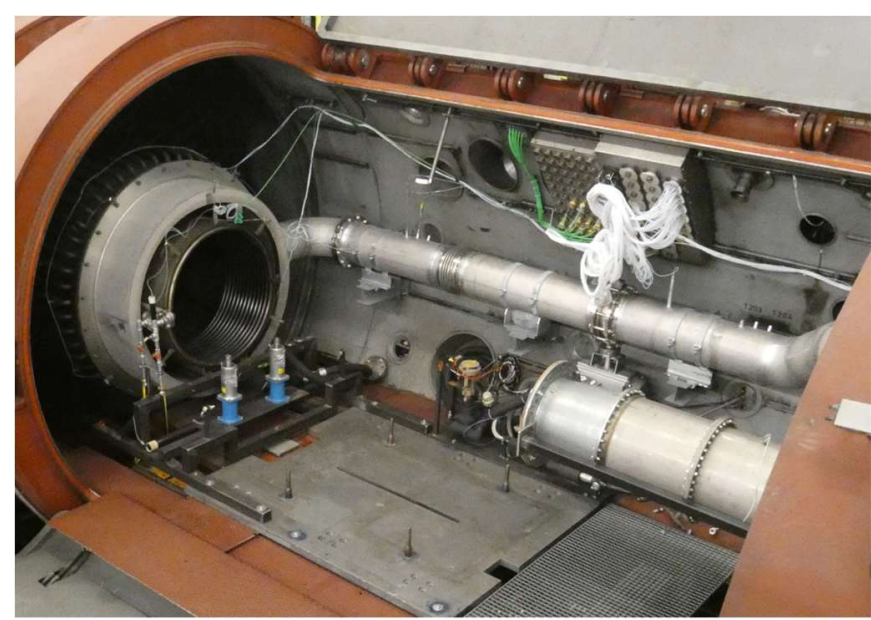

Figure 6: Bypass integrated into test cell 1

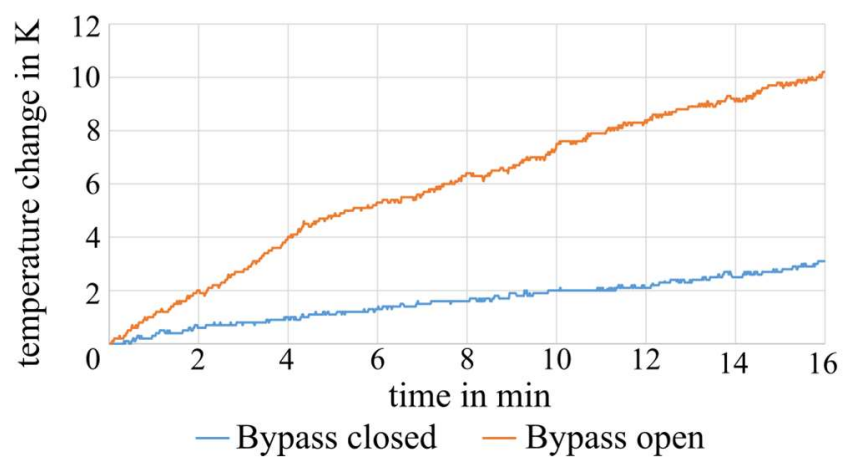

Figure 7: Cooling process
A significant reduction of cooling time has been realised using this bypass system. The rate of temperature change has been tripled as is shown in Fig. 7.

The bypass system can be installed and removed in short time if required.

Furthermore the fuel supply system has been optimized to provide low temperature fuel with minimum temperature fluctuations. Improved isolation and a reduction of the fuel pipe volume have been realized as shown in Fig. 8.

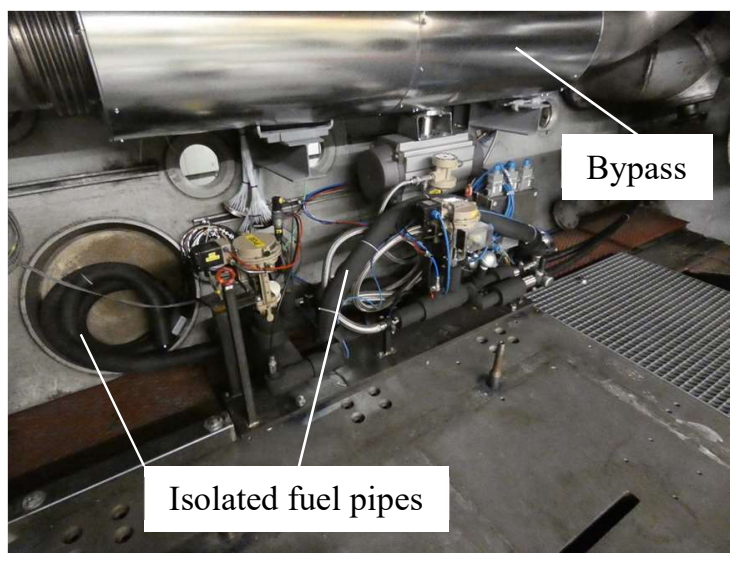

Figure 8: Reduced volume, Isolated Fuel Supply

As a result temperature stability has been improved as shown in Fig. 9.

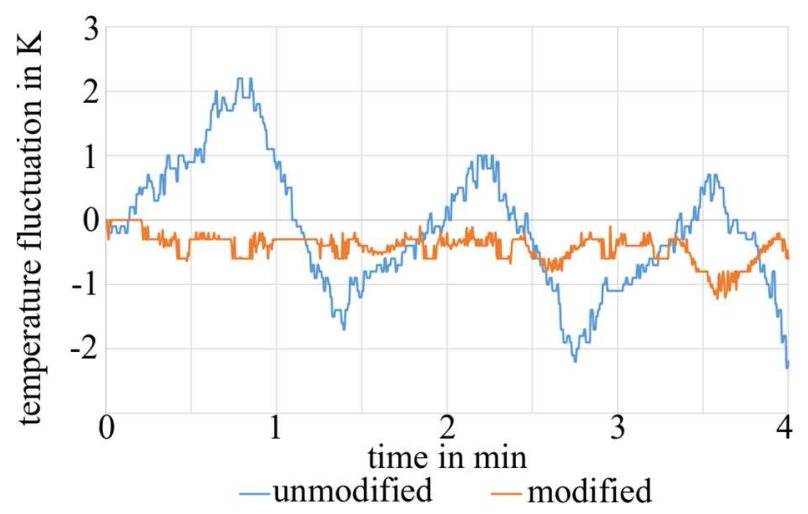

Figure 9: Fuel Temperature Stability

\section{SP-2 IMPROVEMENTS FOR FUTURE TURBINE AERODYNAMIC TESTING}

Highly sensitive instrumentation such as hot films, hot wires and Kulite sensors are a state of the art enabler for turbine aerodynamic testing. The use of such types of instrumentation had to be considered and has led to a carefully chosen increase of turbine inlet temperature. The integration of a new heat exchanger into ATF has been realized to achieve these goals (see Fig. 9).

The heat exchanger comprises an air - thermal oil heat exchanger with a thermal power consumption of $6500 \mathrm{~kW}$ and an additional electrical heat exchanger $(500 \mathrm{~kW})$ located downstream. The electric heat exchanger is used for precise adjustment of the temperature at rig inlet. Rig inlet temperatures of up to $620 \mathrm{~K}$ are possible. With the new heat 
exchanger a higher total heat quantity is yielded, which also allows to shorten the heat up times.

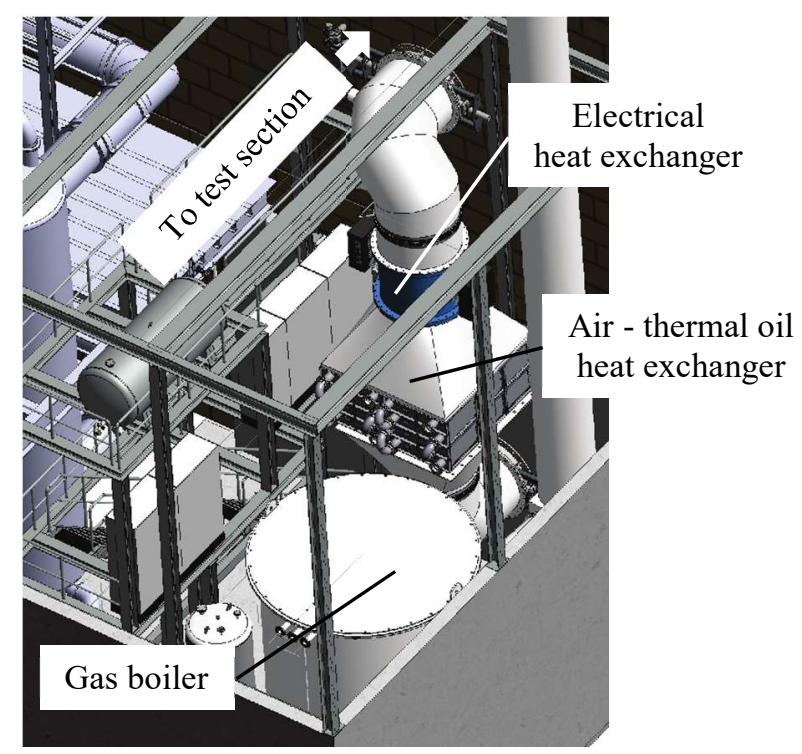

Figure 10: Heat Exchanger and Sub Systems

For turbine testing the test facility is operated in the so called "closed loop operation mode" which is comparable to the operation of a wind tunnel of Goettingen-type. In "closed loop operation mode" all compressors must be equipped with an aftercooler system. Hence one of the compressor which has not been used for turbine testing up until now is being equipped with an aftercooling system within FoTeKo. As a result the total compressor pressure ratio across the test rig increases.

The compressors at ATF are designed for different air mass flows. Compressor V3 is a radial compressor with max. value of $15 \mathrm{~kg} / \mathrm{s}$. Therefore it is driven by a smaller machine than the other compressors, which are designed for higher air mass flows. So the newly available compressor additionally enables cost-effective testing of smaller test vehicles like cascades and small engines.

\section{SP-3 IMPROVEMENTS FOR FUTURE CORE ENGINE TESTING}

A next step in automation of the ATF operation is required to fulfil the requirements of future core engine testing. This activity is embedded in the current replacement of the ATF control system. The automation has been realized step by step to give the operators the possibility to buy into the new operational concept. The stringent safety and reliability demands of ATF testing require a consistent approach for definition, design, realization and validation of all systems contributing to automated facility operation. A first automation step has been demonstrated for combustor testing. For this particular type of testing the ATF is operated in so called "suction mode". It is described using the simplified ATF scheme documented in Fig. 11.

Air is taken from ambient atmosphere and is conditioned and dehumidified by the ATF. The valves and the heat exchangers arranged immediately upstream of the test cell are used to provide the required rig inlet conditions. Thereby the required inlet temperature is achieved by mixing air mass flows with different temperatures. The required inlet pressure is achieved by opening or closing the control valves. For maintaining the inlet temperature, the ratio of valve opening angle has to be constant. During the combustion process soot and other exhaust gases are generated. Hence air as well as exhaust gases leave the test cell. As a result, the energy-wise advantageous "closed loop operation mode" cannot be used and the air has to be discharged into the ATF environment. This is achieved by running one or more compressors, which can operate in serial or in parallel.

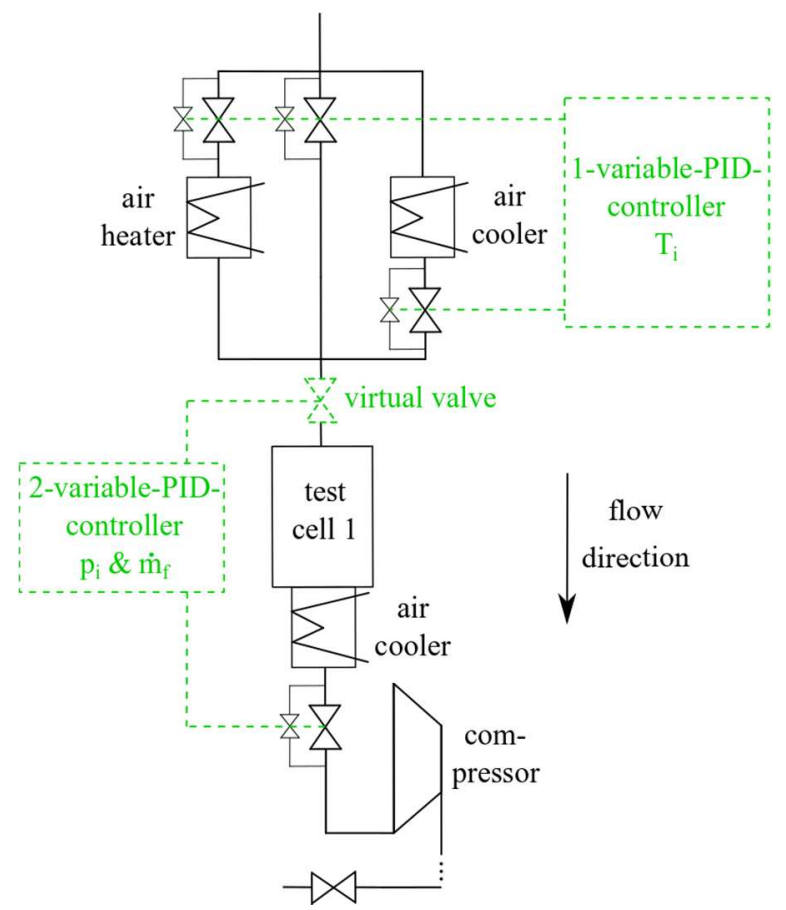

Figure 11: Simplified ATF Scheme

For this type of operation the ATF controller exploits a combination of two controller types. For controlling inlet pressure and mass flow a 2-variable-PID-controller is utilized. Its regulating variables are on one hand the valves downstream the test cell. On the other hand the valves upstream the test cell are combined to a "virtual valve". By variation of the opening angle the inlet pressure is modified. For controlling the inlet temperature a cascaded 1-variable-PID-controller is used. It controls the opening angle ratio of a warm and a cold strand, providing that the pipe selection is variable. This structure allows high flexibility with regard to adjusting the inlet conditions and is applicable for other test types in a modified form.

Currently the ATF controller passed a number of combustor tests with good results. In Fig. 12 the automated adjustment of the air mass flow while maintaining the inlet pressure can be seen.

First, a massflow which deviates from the nominal value was set manually and afterwards the controller has been started. A moderate undershoot of the air mass flow and a moderate overshoot of the inlet pressure can be seen. Over- 
and undershoots in the adjusting process are noncritical and the controller is fast enough for dynamic manoeuvres like lean blow off or weak extinction. Repeatability of the tests has been increased and the work load for the operators has been reduced.

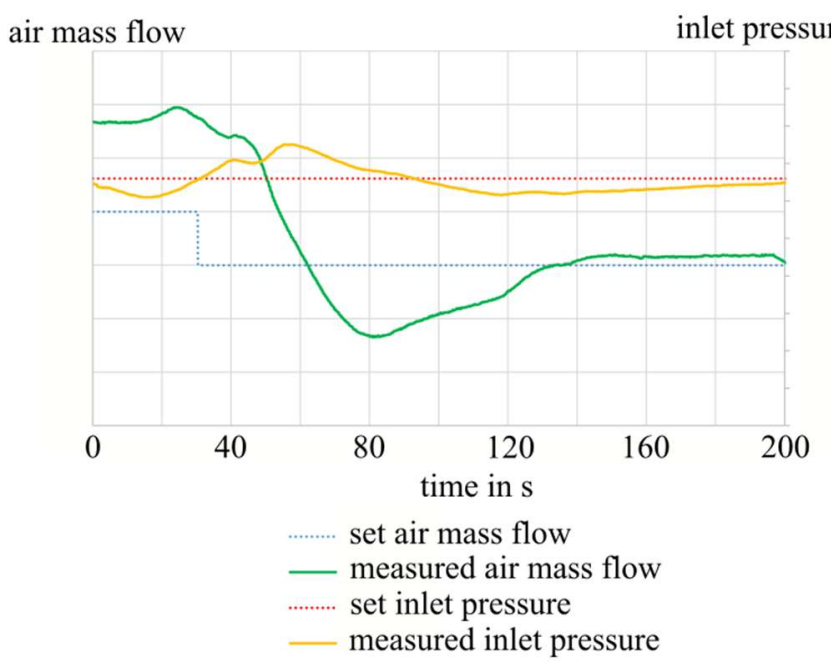

Figure 12: Automated Adjustment of Test Conditions

\section{NEXT STEPS AND COMPARISON TO OTHER TEST FACILITIES}

After the modifications described above, the ATF features a wider operating range. This is documented in Table 1. Within FoTeKo SP-1 new exhaust casings have been procured which got a higher number of measurement points and the possibility to adapt the number and positions of these points to the burners of the test rig. A new visualization which allows a good characterization of the burner performance was introduced. As well fuel temperature stability has been improved. These modifications enables a better experimentally investigation of lean burn technologies and will be useful for characterization of the resultant flow field.

Within FoTeKo SP-2 a new heat exchanger, which enable inlet temperatures up to $620 \mathrm{~K}$ was integrated into ATF. Also the compressor V3 was equipped with an aftercooler system. By this modification higher inlet temperatures and pressure ratios for future turbine testing can be provided. Also the possibility for cost-effective testing smaller vehicles has been created.

By the controller system for combustor testing within FoTeKo SP-3 the basis for the development of core engine testing with automated adjustment of operating conditions has been created. Today the controller is used for partially automated combustor testing and passed a number of tests with good results.

Integration of a bypass into test cell 1 and the installation of new heat exchanger LW32 into test section 2 results in a higher ratio of measurement to transition times.
Comparing the ATF after FoTeKo to other test facilities (see Table 1) for engine and component testing shows, that the modification have been selected carefully and rightly. Stuttgart University's ATF complements the capabilities at national and international level.

Its main advantage is the high flexibility regarding to rig installation, test type and operational range. By having two test sections testing a rig at test section 1 during the installation of another (like a turbine) on test section 2 is possible. This means that a quick pace between two tests can be realized. Despite the wide range of test types, the conversion of the tests in one test section is short. Whereas some of the other test facilities are specialized at one component type (for example NG-Turb and Transonic Test Turbine Facility are turbine test facilities and DLR HBK4 is a combustor test facility), testing engines as well as engine components like combustors or turbines at ATF is possible. Also basic tests as cascades are feasible. Furthermore the air heaters and air coolers enables adjusting test points with an inlet temperature below or above $273 \mathrm{~K}$ and an inlet pressure below or above barometric pressure. This means simulation of altitude conditions (for example for restart tests in high altitude up to $21000 \mathrm{~m}$ ) as well as tests at sea level (for example high speed tests up to Mach 2,2) are possible. Stuttgart University's ATF features relatively small dead volumes, so it is able to perform highdynamic manoeuvres (for example within tests of core engines).

Table 1: Overview of some European altitude and component test facilities

\begin{tabular}{|c|c|c|c|}
\hline Test facility & $\begin{array}{l}\text { Inlet } \\
\text { pressure } p_{i}\end{array}$ & $\begin{array}{l}\text { Inlet } \\
\text { temperature } \\
T_{\mathbf{i}}\end{array}$ & $\begin{array}{l}\max . \text { air } \\
\text { mass } \\
\text { flow } \dot{\mathbf{m}}_{\mathrm{f}}\end{array}$ \\
\hline $\begin{array}{l}\text { ATF after } \\
\text { FoTeKo } \\
\text { test section } 1 \\
\text { test section } 2\end{array}$ & $\begin{array}{l}5-240 \mathrm{kPa} \\
5-220 \mathrm{kPa}\end{array}$ & $\begin{array}{l}200-430 \mathrm{~K} \\
200-620 \mathrm{~K}\end{array}$ & $\begin{array}{l}130 \mathrm{~kg} / \mathrm{s} \\
130 \mathrm{~kg} / \mathrm{s}\end{array}$ \\
\hline $\begin{array}{l}\text { DGA (Air } \\
\text { Transport } \\
\text { Net, 2016) }\end{array}$ & $5-350 \mathrm{kPa}$ & $208-373 K$ & $140 \mathrm{~kg} / \mathrm{s}$ \\
\hline $\begin{array}{l}\text { NG-Turb } \\
\text { (Roehle, } \\
\text { 2011) }\end{array}$ & $10-200 \mathrm{kPa}$ & $300-700 \mathrm{~K}$ & $9 \mathrm{~kg} / \mathrm{s}$ \\
\hline $\begin{array}{l}\text { Transsonic } \\
\text { Test Turbine } \\
\text { Facility } \\
\text { (TTM, 2001) }\end{array}$ & $\max .500 \mathrm{kPa}$ & $313-458 \mathrm{~K}$ & $20 \mathrm{~kg} / \mathrm{s}$ \\
\hline $\begin{array}{l}\text { DLR HBK } 4 \\
\text { (Institute of } \\
\text { Propulsion } \\
\text { Technology, } \\
\text { 2018) }\end{array}$ & $\max .400 \mathrm{kPa}$ & $\max .973 \mathrm{~K}$ & $45 \mathrm{~kg} / \mathrm{s}$ \\
\hline $\begin{array}{l}\text { ECAT } \\
\text { (Kirollos et } \\
\text { al., 2017) }\end{array}$ & $\begin{array}{c}100- \\
1000 \mathrm{kPa}\end{array}$ & $290-370 \mathrm{~K}$ & $30 \mathrm{~kg} / \mathrm{s}$ \\
\hline
\end{tabular}




\section{CONCLUSION}

In this article requirements of future propulsion systems with regard to component testing by example of Stuttgart University's Altitude Test Facility were identified. Considering actual tendencies of development the need for higher inlet temperature, inlet pressure and pressure ratio for turbine testing was recognized. Also there is the need for fuel conditioning, stable combustor flow conditions and repeatable and reliable thermodynamic detection of lighting and pullaway. Furthermore the requirement for an automated adjustment of test conditions for core engine tests was determined. As a result selected improvements have been made to Stuttgart University's ATF improving its capability, its operation as well as its agility. These improvements have been implemented successfully leading to a facility which complements well the test facilities available nationally and internationally.

\section{NOMENCLATURE}

$\begin{array}{ll}A C A R E & \begin{array}{l}\text { Advisory Council for Aviation Research an } \\ \text { innovation in Europe }\end{array} \\ A T F & \text { Stuttgart University's Altitude Test Facility } \\ C E T & \text { Combustor Exit Temperature } \\ D L R & \text { German Aerospace Center } \\ E C A T & \text { Engine Component AeroThermal } \\ \text { FoTeKo } & \text { Advanced Technology and test concepts for } \\ & \text { turbines, combustors and core engines } \\ I L A & \text { Institute of Aircraft Propulsion Systems } \\ L P & \text { Low Pressure } \\ L P T & \text { Low Pressure Turbine } \\ N G & \text { Next generation } \\ O P R & \text { Overall pressure ratio } \\ \dot{\mathrm{m}}_{\mathrm{f}} & \\ \mathrm{p}_{\mathrm{i}} & \text { mass flow in kg/s } \\ \mathrm{T}_{\mathrm{i}} & \text { inlet pressure in } \mathrm{kPa} \\ & \text { inlet temperature in } \mathrm{K}\end{array}$

\section{ACKNOWLEDGMENTS}

This work has been done in the context of the LUFO V-2 project "FoTeKo". The authors gratefully thank the German Federal Ministry for Economic Affairs and Technology (BMWi) for funding.

Funding Data: Bundesministerium für Wirtschaft und Energie (20T1506C).

The authors also gratefully thank the Ministry for Science, Research and the Arts of the State of BadenWuerttemberg for funding.

Furthermore we thank MTU Aero Engines and RollsRoyce Deutschland for their continuous and ongoing support.

\section{References}

Advisory Council for Aviation Research and Innovation in Europe (ACARE) (2017). Strategic research \& innovation agenda. 2017 Update. Executive summary. Cited: 14.07.2018 https://www.dlr.de/dlr/Portaldata/1/Resources/documents/20 17/acare-strategic-research-innovation-summary-220170613.pdf

Air Transport Net (2016). R6. Cited: 11.07.2018. https:/airtn.eu/wp-content/uploads/airtn-dga-r6.pdf

Braig W. et al. (1987). Erweiterung des Stuttgarter Höhenprüfstandes (ILA-87 B 08), Schlussbericht BMFTFördervorhaben 514-8891-LVP 8401I0. Institute of Aircraft Propulsion Systems. Final report of the funding plan.

Clemen C. et al. (2017). Full annular combustion rig testing with high-pressure turbine nozzle guide vanes. In: Deutscher Luft- und Raumfahrtkongress 2017.

Gonser H. (2008). Untersuchungen zum Einsatz von Wärmetauschern in zivilen Turboflugtriebwerken. $\mathrm{PhD}$ thesis, Institut for Aircraft Propulsion Systems, University of Stuttgart.

Hechtel K. (1987). Höhenprüfstand für Turboflugtriebwerke (ILA-87 A 02). Institute of Aircraft Propulsion Systems. Technical report.

Institute for Thermal Turbomachinery and Machine Dynamics (TTM) (2001). Transonic Test Turbine Facility. Graz University of Technology. Cited: 19.07.2018.

http://ttm-

old.tugraz.at/facilities/testrig/description_turbine.pdf

Institute of Propulsion Systems (2018). High Pressure Combustion Chamber Test Rig 4 (HBK4) Cologne. Cited: 11.07.2018.

https://www.dlr.de/at/en/desktopdefault.aspx/tabid1530/2446_read-3812/

Kirollos B. et al. (2017). ECAT: An engine component aerothermal facility at the University of Oxford. In:

Proceedings of ASME Turbo Expo 2017: Turbomachinery Technical Conference and Exposition.

Klinger H. et al. (2011). Altitude testing of the E3E core engine. In: Proceedings of ASME Turbo Expo 2011:

Turbomachinery Technical Conference and Exposition.

MTU Aero Engines (2011). Spitzentechnologie made by MTU. Cited: 17.07.2018. http://www.mtu.de/epapers/MTU_ePaper/Marketing/Spitzentechnologie_made_b y_mtu/epaper/ausgabe.pdf

Rick H. (2013). Gasturbinen und Flugantriebe: Grundlagen, Betriebsverhalten und Simulation. Springer Vieweg.

Roehle I. (2011). Neuer Turbinenprüfstand NextGeneration Turbine (NG-Turb). German Aerospace Center, Institute of Propulsion Technology. Cited: 19.07.2018. https://www.dlr.de/at/Portaldata/20/Resources/dokumente/tu/ NGTurb_web.pdf

Von der Bank R. et al. (2014). LEMCOTEC - Improving the core-engine thermal efficiency. In: Proceedings of ASME Turbo Expo 2014: Turbomachinery Technical Conference and Exposition. 